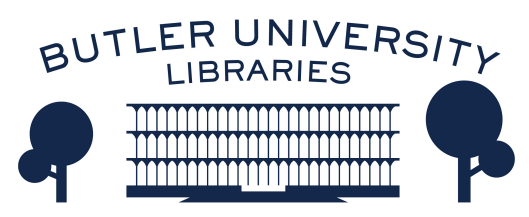

Journal of Hindu-Christian Studies

Volume 26

Article 5

November 2013

\title{
Becoming Different: Why Education is Required for Responding to Globalism Dharmically
}

Jonathan Edelmann

Mississippi State University

Follow this and additional works at: https://digitalcommons.butler.edu/jhcs

Part of the Religion Commons

\section{Recommended Citation}

Edelmann, Jonathan (2013) "Becoming Different: Why Education is Required for Responding to Globalism Dharmically," Journal of Hindu-Christian Studies: Vol. 26, Article 5.

Available at: https://doi.org/10.7825/2164-6279.1544

The Journal of Hindu-Christian Studies is a publication of the Society for Hindu-Christian Studies. The digital version is made available by Digital Commons @ Butler University. For questions about the Journal or the Society, please contact cbauman@butler.edu. For more information about Digital Commons @ Butler University, please contact digitalscholarship@butler.edu. 


\section{Becoming Different: Why Education is Required for Responding to Globalism Dharmically Jonathan Edelmann Mississippi State University}

THE content of this article is based on an invited presentation about Being Different: An Indian Challenge to Western Universalism by Rajiv Malhotra for the Society of Hindu-Christian Studies at the 2012 American Academy of Religion. I have taken into consideration some of Mr. Malhotra's comments after the panel presentations, as well as a subsequent email exchange.

In Being Different Mr. Malhotra critiques Western thought from what he calls a "dharmic perspective," something I was very glad to see and hope will inspire other such critiques. Much of my work has also sought to expose underlying and often unjustified assumptions in Western thought, another reason I initially greeted his book warmly. Despite being supportive of Mr. Malhotra's goals and efforts, and despite my sincere wish to read critiques of Western thought from Indian perspectives, I think his book raises a number of "red flags," to which I hope he and his readers will attend. My conclusion is that for those who wish to learn something substantial and accurate about dharma traditions, there are far better sources than Being Different.
Malhotra's approach bears some
similarities to Shrinivas Tilak's essay "Hinduism for Hindus: Taking Back Hindu Studies" (see Hawley and Narayanan 2006), both of whom wish to recover India from Western conceptual contamination. But in my understanding, neither one provides a tenable plan for doing so, which must, in my view, involve a robust educational program. Although necessary, I do not think that published material and book promotion lectures will generate the large-scale critique of the West and the reevaluation of the East for which they call. At this point in American history the Hindu community is financially well established and socially well placed, both of which bode well for the establishment of educational programs for Hindus in all phases of life. At this time there are very few places in the USA, UK or EU where Hindu children, youth, young adults and adults can go to receive a Hindu (or dharmic if you prefer) education other than the very educational institutions of which Malhotra and Tilak are so critical and dismissive, i.e., universities and colleges wherein the programs are for the most

Jonathan Edelmann is an Assistant Professor of Religion at Mississippi State University in the Department of Philosophy and Religion. He was a 2009-2011 Luce Summer Fellow with the American Academy of Religion and a winner of a 2011 John Templeton Prize for Theological Promise. He is the author of Hindu Theology and Biology: The Bhāgavata Purāna and Contemporary Theory (2012) with Oxford University Press, and has written for Zygon, the Journal of Vaishnava Studies and the Journal of the American Academy of Religion.

Journal of Hindu-Christian Studies 26 (2013):17-27 
part run by white men and women. This seems to be the foundation of all the problems raised by Malhotra and Tilak because without educational facilities to reclaim the India contaminated by the West and without educational facilities to teach those reclaimed views there can be no sustained critique of the West. I discuss this more in the final portion of this article.

\section{Whose India? Whose West?}

I admire that Malhotra takes a stand and argues his views with passion. But on what is he taking a stand? If BD is meant to represent Indian intellectual history or something like an essential "dharmic" perspective, then the book misleads for reasons I discuss below. On the other hand, if BD's discussion of the "dharmic traditions" is only meant to represent Rajiv Malhotra's worldview, which he has constructed from a smattering of Indian and Western sources, then the book is just that and could only be evaluated in terms of its cogency. So is BD a historical reconstruction of Indian thought, or is it Malhotra's personal views?

The text itself clearly indicates the intention to be the former (with terms like "the dharmic perspective" throughout its pages rather than "a dharmic perspective," italics my own), but maybe Malhotra misspeaks or is unfamiliar with the difference "a" or "the" makes. Think, for example, about the impact that the difference between "the theory of evolution" and "a theory of evolution" has made in American legal and educational contexts. In his response to the panel discussion Malhotra said BD's characterization of the dharma traditions are his views alone, and that they are not meant to be representative of the Indian tradition(s) in general. I do not see how that view can be justified on the basis of what he has is written in the BD itself. For instance, the first sentence of the Conclusion reads: "The preceding chapters have dealt with some major differences between the West and India" (BD, 338; italics my own). This indicates that $\mathrm{BD}$ is meant to be representative of what Indians in general think, not merely Malhotra's own views. I am not sure that he is aware that if $\mathrm{BD}$ is merely his views that this would undermine the entirety of his project, since his goal is to show that Indian thought has been misunderstood. I am, therefore, going to take $\mathrm{BD}$ as an attempt to tell us what is essentially true about dharmic traditions since that is how the text presents itself.

In addition to what is discussed above, there are other methodological problems with the text, which seem to stem from Malhotra's conflation and confusion of what he thinks India was with what Indic thought might be; Malhotra does not demark the two projects in his book, and thus he frequently misleads his readers. For example, Malhotra argues there is an inherent split between science (=Greek) and religion (=Judeo-Christian) in the West, which the John Templeton Foundation attempts to repair, but that India is free from such problems. Malhotra holds a major misconception about the interaction of the sciences and the theologies of the West, or at the very least he glosses over the history of science and religion in the West. It is well known, for example, that Sir John Templeton thought that science is a form of theology, and that the separation between the two was the result of an inadequate understanding. Malhotra thinks the JTF is about reordering Western science-religion relationships, whereas I see it as attempting to educate 
people about the way it really is as opposed to the way it superficially appears to be.

Furthermore, Malhotra thinks there are two things ("science" and "religion") that are clearly distinguishable from one another. As I have noted (Edelmann 2012; Edelmann 2012a), historians have rejected essentialized notions of "science" and "religion" (Brooke 1991; Harrison, Numbers and Shank 2011). They are not, as Malhotra believes, clear and distinct categories, but fluid and dynamic, subject to revision by thinkers in different historical contexts; the science and theology of Isaac Newton, for example, is different than that of Charles Darwin, who is himself different from Richard Dawkins. Malhotra thinks that "efforts to substitute creationism for Darwin's theory of evolution" point to great and irresolvable tensions in the West, but he is clearly unaware of the fact that Darwinism quickly and repeatedly gained support from Western thinkers, both scientific and religious, as many of the standard histories have noted. Christian Creationism is rejected by all the major Christian denominations, whereas Malhotra seems to think it is a mainline view. If Malhotra had spent some time outlining, for example, how Western scientists and Abrahamic theologians have worked through issues of natural knowledge and scriptural exegesis, he might have presented a nuanced view of science and religion, one that adequately reflects the complexity of Western thought, and one which would serve as a real and genuine pürva-pakșa rather than the straw-man argument we have in BD.

There are straw-man arguments on the dharmic side as well. Malhotra falsely thinks that India is free from the defects of the West: "By way of contrast [with the West], not even the most orthodox Hindu, Buddhist or Jain leaders are inclined to argue against the evolution of the cosmos, or any other science for that matter. Some modern scientists with dharmic worldviews have also questioned Darwin's theory, though these questions pertain to the science behind the theory and have nothing to do with religious dogma" (BD, 149-50). This is just as wrong as his view of science-religion relations in the West. C Mackenzie Brown's Hindu Perspectives on Evolution (2012) provides a realistic and historically accurate depiction of Hindu views on the natural sciences, a text that Malhotra would benefit from reading. Many contemporary Hindu thinkers did question the science behind Darwinism, e.g., Bhaktivedanta Swami. Had Malhotra conducted even basic research it would reveal that many Indian thinkers (classical, modern, etc.) argued against evolution on the basis of religious belief derived from canonical texts like the Purānas, Vedānta Sūtra, Bhagavad Gìtā, Veda Saṃhitās, etc. Furthermore, there were even debates within India about the status of natural knowledge and scriptural exegesis long before its encounter with European sciences. As noted in Edelmann (2012), there were over 1000 years of debate between the followers of the Purānic cosmology and the followers of the Siddhāntas (a more quantitatively based cosmology), a debate that cannot be simplistically reduced to one of agreement between the scriptural exegetes and the mathematicians. Malhotra contends that the West is fragmented and conflictual, whereas India is unified and harmonious, but histories on each side tell a different story. Again, if Malhotra had given some time to relating to us the history of India 
thought in its particulars, such major errors might not have occurred.

While I admire the tenacity with which Malhotra address issues of science and religion, as well as the passion that he brings to the discussion, I think there is still considerable work to be done regarding the historical and philosophical clarity with which he engages the issues.

\section{What is Essential in the Dharmic Traditions?}

In BD Malhotra wants to find what is essentially dharmic by carefully selecting the primary and common features one finds in the traditions of India. This is a particular approach to the study of India that I have not adopted because I favor a more tradition-based approach wherein specific texts out of specific schools are addressed. However, a generalist approach is one that others have taken, and one which I think can be done well. For example, Arvind Sharma's recent book, One Religion Too Many: The Religiously Comparative Reflections of a Comparatively Religious Hindu (SUNY, 2011), is a brilliant, bold, honest and illuminating attempt to highlight some of the general features of Indic thought. However, Malhotra's selection of ideas is misleading and despite his occasional insights and interesting comments, his discussion obfuscates the nature of the dharmic traditions. As I discuss below, I think that if one is looking for something essentially Indian or dharmic, there are far better places to go than Being Different. I cannot address all of his points, but I focus on what he considers the most important, i.e., the role of history.

\section{History}

Malhotra makes four distinctions between East and West. His first distinction is that of "embodied knowing versus history-centrism" $(\mathrm{BD}, 5)$. Here I wish to explain why this is a false distinction, one that prevents an accurate understanding of East and West. I will say something about Malhotra's views on history from a Gaudiya Vaiṣnava point of view, particularly that of Jivva Gosvāmin, a theologian Malhotra discusses in his appendix. Malhotra says that the Purānas, "do not have a specific origin, nor are they attributed to a specific author. There were various compilers who function in a decentralized manner" (BD, 242). This view undermines the North Indian Bhakti schools, especially that of Vallabha and Caitanya, both of which take the Bhägavata Purāna as the central theological authority, and Vyāsa as its author.

For Gaudīya Vaiṣnavas the Bhāgavata Purāna is a śāstra that is the essence or sāra of the Vedic tradition, culled by Vyāsa after mature reflection and consultation with his guru, Nārada. Surely there are many narrative frames within the text (e.g., Viṣnu $\rightarrow$ Brahmā; Śuka $\rightarrow$ Parikssita; Sūta $\rightarrow$ Śaunaka; etc.), but the text is ultimately seen as a unified composition, edited by Vyāsa himself. They believe it to be a coherent theology, one which represents Vyāsa's most important articulation and most significant vision ( $\sqrt{ } p a s ́)$ of the divine. These ideas are all expressed in the First Book of the Bhāgavata itself. Jīva Gosvāmin argues in his Tattvasandarbha that Vyāsa's insight or samādhi is the source of the Bhāgavata's teachings, and that his authorship - at a particular time and location in history - is what gives the śāstra its authority over all other Purāṇic, Upanișadic and Vedic śāstras (Dāsa 1995). He makes this 
view the epistemological foundation of his entire theology. It is the historical reality of Vyāsa's insight and vision of the divine at a particular point in the history of Indian thought that allows the Gaudiya Vaiṣnavas to interpret the entirety of the Hindu canon with a bhakti (devotional) perspective, seeing it as a development out of Vedic ritualism (karma) and Upanișadic non-dualism (jñāna). Gauḍiya Vaiṣnavas also believe Vyāsa divided the one Veda into the four Veda Saṃhitās, and composed Mahābhārata and Vedānta-Sūtra at particular points in history.

My point is not to say that Vyāsa is in fact the author of the Purānas, Itihāsa, or other sāstras. Nor am I saying Malhotra should believe this, or that to be part of the dharma traditions one must believe this. There are many that would not, e.g., the radically dehistorizing Pūrva-Mīmāmsā school. But if we are to consider North Indian Bhakti traditions part of the dharmic tradition, then Malhotra is misleading his readers.

Regarding his second point, Malhotra feels he has uncovered a great truth - that Western religions are historically oriented, that they see salvation as resting on particular historical events, that God is revealed in and through historical developments, etc. This is obvious to anyone that has spent even a little time reading Western theologies and philosophies, and I am not sure why or how Malhotra thinks this is a great insight, calling it the "central pillar" of his book. Malhotra was angry at the panel sessions and thereafter that the respondents had not commented on this point, saying we were not real scholars because we hadn't addressed it. But to me it seemed obvious and unworthy of much attention. Nevertheless I shall say something about it here.
Malhotra argues that the history-centrism or historical fixation of the West is "the major difference between the dharmic traditions," and that this historical fixation undermines the individual, and creates "psychological, religious and social conflict" (BD, 6). Throughout his text he provides an articulation of dharmic traditions that is totally devoid of a need for or dependence on history, going so far as to say that "my dharma would survive even without historical records." In his view, "yoga techniques and practices are independent of the life history of Patañjali," and "bhajanas (devotional songs) are not history-centric, nor are they dependent upon a belief in the lives of the bhakti saints who composed them" (BD, 61).

Firstly, I think this is incoherent philosophy, and secondly I do not think it accurately represents what all the dharmic traditions are saying. Certain aspects of Hinduism are in fact very much dependent on history, and indeed all religious traditions (= sampradāya in Hinduism) are dependent upon a history, and that is one reason why Hindu traditions are keen to outline their paramparā, or line of teachers (e.g., at the conclusion of the Brhadāranyaka Upanișad). Brahman may be above the vicissitudes of time, but teaching about Brahman has a history and a context. We know about Brahman or Purusa in and through a tradition; see, for example, Vyāsa's, Vijñānabhikṣu's, Vācaspatimiśra's, commentaries on the word anuśasana in the Yoga Sütra. No doubt the ways these issues are thought of in each Hindu tradition are different than in Abrahamic traditions, but what is needed is a more nuanced and less reactive analysis, one that sees the deep structural similarities while noting the differences. Malhotra does not provide us with that. 
Malhotra might simply be saying that the foundational truths in sampradāya are not tied to a historical event in the same way that Abrahamic religions are, but then how do we know of the foundational truths in dharmic traditions if not by their emergence out of particular historical events? Perhaps Malhotra is a closet or unknowing follower of PūrvaMīmāmsā, which wants to say the Veda and the world have always been here? I shall get to that later.

In my course on Hindu Narrative Traditions for undergraduates I begin by introducing various ways that Hindu thinkers conceive of historical and narrative information in the Itihāsas, Purāṇas, Vedas, etc., and that might be a good place to start here as well. There are radically non-historical conceptions, e.g., Pūrva-Mīmāmsā's notion of arthavāda, which says that all stories in the Vedas are merely meant to inspire ritual performance and they are in no way historical events. Oddly, Malhotra does not talk about that in his book, even though he seems to have sympathy with it (although probably not the ritualistic and injunction parts). Vaiṣnavas think of the activities of Viṣnu and Kṛ̣na as līlà, a divine play, but part of the divine play is to intervene in the ways of history, often at the behest of gods like Brahmā and in response to the emotional attitudes (bhāva) of his devotees. In fact the famous churning of the ocean of milk story (Edelmann, forthcoming), which is featured on the cover of Malhotra's book, is an instance in which Viṣnu appears as a tortoise within history for specific reasons. Indeed it is a central teaching of the Bhagavad Gitā (e.g., Chapter Four) that the Lord descends into the world to sustain dharma at particular historical moments. The Rāmāyana, Mahābhārata,
Purāṇas, etc. all say that Rāma and Kṛṣna appeared for reasons that were rooted in the history of our human world.

Some do see these stories as real and literal events in the human past, i.e., aitihāsika. For example, the South Indian Vaișnava Madhva Ācārya's Tātparyanirnaya commentary on the Mahābhārata says there are three ways to read each verse of the Mahābhārata: āstikādi - the historical events of the Pāndavas and Krishna; manvādi - the lessons on morality, virtue, divine love, duty, Brahman; and auparicara transcendent or spiritual, wherein every word is shown to relate to the Lord. Jiva Gosvāmin argues in his Krșnasandarbha that the holy land of Vṛndāvana is holy because of the Lord's appearance in it, that his life in it made it a manifestation of his eternal, spiritual realm (prakāśa-viśeșa). One might say, then, that there is a history that makes Vṛndāvana special to Vaiṣnavas, and the reasons for visiting it is to facilitate meditation on the Lord (smarana) and to meet holy people (sādhu-sanga), but the land itself has also been made holy by the Lord's historical appearance therein.

In the Gaudīya Vaiṣnava tradition, Vyāsa acts something like a Vedic rșii according to Jivva Gosvāmin he brings the content of his experience found in samādhi into the world at a particular point in history. Had he not done so, there would be no Vaiṣnava tradition in this world, or it would have had to come about through some other historical process. Likewise, from a Gaudiya Vaiṣnava perspective had Kṛșna not appeared in the Yadu dynasty just before the Kaliyuga and had Vyāsa not composed the Bhāgavata Purāna, there would be no Kṛṣna Bhakti in this world. And for Gaudiya Vaișnavas, Bhakti is the means of salvation, as well as the state of salvation (Edelmann 2009). 
Without these historical events we would not be having a conversation about this dharma, and Malhotra could not be saying this dharma does not depend on history!

Perhaps Malhotra does not think these thinkers are part of the dharmic tradition, but he rarely provides any examples from the Indian tradition itself to back up his views, so it is unclear who in Malhotra's mind counts as a dharmic thinker or what counts as a dharmic text.

Malhotra notes that there are Christians who see their salvation and the existence of their religion in the historical incarnation of Jesus. There are Christians who question that assumption, but to his fault Malhotra does not engage with the diversity within Christian theology. However, the problem I wish to highlight here is that Malhotra wants to say the dharma traditions are entirely free from such historical conceptions of religion. Vaiṣnavas, for example, see their salvation as resting upon the Lord's appearance in this world, lest they would not know of him, and without knowledge of the Lord there is no devotion for the Lord. These topics are discussed in the Fourth Chapter of the Bhagavad Gitā, for instance.

There is a larger issue here, one that has nothing to do with dharma traditions in particular, but just a common sense view of religion. Malhotra wants to say that the science of the self (adhyātmavidy $\bar{a}$ ) is above time. Surely one can say that is how dharma traditions conceive of the atman itself, but the fact that we are able to say anything about the atman at all required a series of historical events, not the least of which is scholars translating Sanskrit texts into the vernacular languages that Malhotra, myself and others can read. Malhotra, for example, who I assume is not a fluent Sanskrit reader given the absence of any reference to Sanskrit texts in his bibliography, might ask himself how indebted he is to the historical events of the nineteenth century in which European scholars translated Sanskrit texts into English.

While a Christian might say that their salvation depends upon the historical interface between God the Father and God the Son in the world of humans in history as the incarnation, Hindus too might say that their salvation (mokșa and bhakti) depends on a series of historical events in history, including the composition of saāstras, their preservation over the course of history, and their explanation at particular points in history by learned teachers. Some Christians (but surely not all) might say Christ's incarnation is totally unique and singular, whereas few Hindus would regard their religion that way. There are surely similarities within these differences and differences within the similarities, but Malhotra has not opened up a subtle comparative analysis on this subject that will allow for a sophisticated comparative dialogue.

Lastly, Malhotra presents a smattering of various thoughts and ideas from India, but not a philosophical or theological system. This, however, is not how dharmic traditions operate. The Vedāntic discourse (which Malhotra hopes to emulate) is based on an argument between a member of one school and a pūrvapakșa to reach a siddhānta, and siddhānta is sāmpradāyika, i.e., it arises out of a particular school of thought. In the Sanskrit literature, scholars work out of one school or another, arguing for their view against other schools - more often than not this is done exegetically and not on the basis of personal experience. As far as I can tell, Malhotra does not have a school of thought 
that he represents or that he is trained in; in my view, this makes for the impossibility of a pürva-pakșa type of discourse as it is construed in the Vedānta Sūtra commentaries. Yet it is a pūrva-pakșsa type of discourse Malhotra seeks to develop. At the same time, there is a failure to recognize the manner in which all our identities are mixed and multilayered. I found Laurie L. Patton, Chakravarthi Ram-Prasad and Kala Acharya's (see Hawley and Narayanan 2006) method of samvāda, or "interlogue" far more convincing and persuasive in their essay, "Hinduism with Others: Interlogue."

\section{Responding to Globalism}

This last point leads me to ask a question of Malhotra: What precisely is the problem with globalization? Furthermore, what is the solution to the proposed problem? Malhotra rightly positions his book as a response to socalled globalism: "The cultural and spiritual matrix of dharma civilizations is distinct from that of the West. The distinctiveness is under siege, not only from unsustainable and inequitable development but also from something more insidious: the widespread dismantling, rearrangement and digestion of dharmic culture into Western frameworks, disingenuously characterized as "universal" $(\mathrm{BD}, 12)$. He uses the term "difference anxiety" to describe Indian's feeling of insecurity on the global stage. He argues that Westerners use difference anxiety to control and subdue the weaker. I fully agree, and I think Malhotra's term is useful and helpful in many ways.

In my understanding, globalization is a new form of colonialism, reborn and repackaged, implemented through war, politics, entertainment, commercial products, advertisement, education, etc. Other civilizations are often reframed in Western terms and categories when brought onto the global stage, yet this is rarely recognized. There is the expectation, which is often enforced through the use of martial power, that other civilizations will fall under the rubric of Western civilization's values. Globalization is in my estimation Europeanization, and I feel strongly that all non-European cultures should be aware and be weary of this.

Why is Europeanization so effective and what to do about it? These are big questions, but here I will say that a contributing cause of the difference anxiety is the lack of widespread education into the dharma traditions, especially for Indians living in the West, whether they were born in the West or moved there from India. I have taught for three years at an American university with great science and engineering programs that draw many good students from India, Sri Lanka, Nepal, and Bangladesh. I have found that they often do not have a basic understanding of Hindu, Buddhist or Jain thought, and worse, they are often contaminated by a belief that ultimately all these traditions and all religions in general are really just teaching "the same thing." And Christianity is saying the same thing, too. Thus, many convert to Christianity within the first years of undergraduate study. And why shouldn't they if it is all the same and if becoming a Christian provides social respectability and reduces the "difference anxiety"?

But what can one expect? How are Indians who do not even know the basic contours of Indian intellectual history going to respond to Western religions and philosophies, especially when their interlocutors do know Western intellectual history, often times very well? And 
many times Christian preachers know Indian intellectual history better than the Hindus to whom they preach. Hindus will not be able to respond to such preachers because they do not know their own history, and this is a cause of their difference anxiety. I believe the lack of education has allowed for a quick digestion of Indian thought into Western thought. There is a general ill-preparedness among Indians in the West to deal with Western thought from Indic perspectives, despite the richness of Indian texts themselves and its vast intellectual resources. I do not know firsthand, but I suspect the same is true in India. I do not wish to be a reductionist, but there is simply no way that dharmic traditions can survive unless there is a concerted effort to educate dharmic practitioners.

Rather than simply blaming the West for subduing and digesting of the dharma traditions, there is a need for Hindu, Buddhist, and Jain, theology, or a learned and sophisticated reflection on tradition in conversation with its new contexts. That theology also must be taught to young men and women who will take up leadership roles in the West. Furthermore, we need to actively and realistically engage dharma traditions in dialogue with the West - that requires education in these Indian traditions at the level of grammar schools, high schools, colleges, universities, and beyond. Writing polemical books is a starting point, but certainly not the end game.

\section{Education and lack thereof}

Ask any scholar working on Sanskrit texts and he or she will tell you how frustrating it can be: Indian libraries allow priceless manuscripts to be eaten by worms and insects, and for fear of them being stolen or misread they are often hesitant to let scholars look at them. The Indian government, the universities and the educated Indians in general have shown marginal concern with text preservation, but it is often too little and too late. Great traditions of learning are in danger of going extinct.

Furthermore, available texts are not widely studied, partly because there is only a handful of scholars able to read and interpret them. Thus even for the Sanskrit texts that do exist, there is a danger that entire branches of Indian learning will not be passed down from master to student. For example, in my own field of study, that of Gaudiya Vaiṣnavism, the masterteacher line that has been passing down the writings of Jīva Gosvāmin, who wrote in sixteenth-century Vṛdāvana, presently hinges on just a few people. While there are a number of us in the Western academic context working on Gaudiya Vaiṣnava texts, we cannot say that we have the deep, seasoned, nuanced and focused understanding of the theologies that the traditionally trained Bābās and Ācāryas have. Yet much of their learning is not being passed on. This is sadly true for many Hindu traditions.

While Sanskrit editions of Jīva Gosvāmin's books are available and most likely will be available for many years to come, there is a real and present danger that the subtle and technical understanding of his books that was cultivated in small but vigorous theological communities in Vṛndāvana and Bengal will die out with the present masters. I have spoken with many colleagues working in other areas of Hinduism, Buddhism, and Jainism who have expressed similar sentiments. 
Much more could be said about the disintegration of traditional Indian learning in India, but perhaps more relevant here is the manner in which Indians have educated themselves in diaspora. Young Indian men and women living in the USA or Europe who wish to learn about their own religious heritage have few options outside Western universities, wherein they will most likely study with the intellectual bearers of the Western's perspectives on Indian civilization that Malhotra argues against. Indian parents who wish to educate their children about Indian religion while living in diaspora have even fewer options. By education I mean something more robust and expansive than learning Mahābhārata stories through Sunday school plays, attending a Satyanārāyaṇa Pūja or reciting the Vișnu-sahasra-nāma. All of these are good and important, but they are not sufficient for responding to the powerful and pervasive influences of globalization that are outlined in Malhotra's book.

I have a BA in Western philosophy and I teach in a Philosophy and Religion Department, so I know that scholars working in Western philosophy and theology are certainly not letting their texts and traditions go to waste. They are studied and taught vigorously every single day.

Despite it merits, I do not think that BD alone can take on the aforementioned problems of Western civilization. We need schools, libraries, teachers, regular classes, journals, books, textbooks, websites, etc. about Indian thought on Western soil, places to give a substantive education to the young (and old) about Indian thought, from which substantive critiques can emerge. Such places do not exist right now, so there is no way that Indians will have the capacity to address Western domination with intellectual dexterity. If Indians are unaware of the richness and complexity of their own tradition, then they will never be able to overcome their difference anxiety and they will never be able to launch the full scale critique of Western civilization that BD calls for.

I raise these educational issues because I think one needs to talk about the solutions to the problem set forth so well in Malhotra's book, and I think that the only solution is education, for it is education that leads to the possibility of critique.

\section{Conclusion: Who is benefited by this book?}

While I so much enjoyed aspects of Malhotra's book, I do not think it can serve as a model for future reflection because the text itself is not steeped in dharmic learning - it is not looking back to Indian texts and traditions as a means of looking forward with sufficient clarity. While I admire the passion and vigor he brings to the discussion, I have raised questions about the scholarly content. There are far better sources of information about dharmic traditions than BD. BD may serve as a road map for directions that could be pursued by more careful scholarship in the future, but this should be done with caution, since many of Malhotra's distinctions between East and West are misleading.

I think it can, however, serve as a call to arms for Indians and scholars of Indian thought to take their own traditions more seriously, to study them more deeply, to set up educational institutions to educate their children in them from cradle to grave, and to use that collective learning to enter into a more substantive 
critique of the West. If anything, Being Different indicates there is a need for becoming different through further study and contemplation.

\section{References}

Brooke, John Hedley. 1991. Science and religion: some historical perspectives. Cambridge: Cambridge University Press.

Brown, Cheever Mackenzie. 2012. Hindu perspectives on evolution: Darwin, dharma, and design. London: Routledge.

Dāsa, Satyanaraya and Jonathan B. Edelmann (forthcoming). "Agency in the Gaudiya Vaișnava Tradition." Free Will, Agency, and Selfhood in Indian Philosophy. Edited by Edwin Bryant and Matthew Dasti. New York, NY: Oxford University Press.

Dāsa, Satyanārāyaṇa. 1995. Śrī Tattva-Sandarbha: the first book of the Śri Bhāgavata-Sandarbha, also known as Śri Șaț-Sandarbha. Vṛndāvana: Jiva Institute for Vaisnava Studies. http://dx.doi.org/2027/mdp.390150383667 $\underline{56}$

Edelmann, Jonathan. 2009, “Argument and Persuasion: A Brief Study of Kirtana in the Bhāgavata Purāna." Journal of Vaishnava Studies. Vol 17, No 2, Spring, pp. 37-56.

_. 2011, Book review of Hinduism Hermeneutics and Hindu Thought: Toward a Fusion of Horizons, edited by Rita Sherma and Arvind Sharma. Journal of Hindu Studies. Vol. 4. No. 2, pp. 207-209. http://dx.doi.org/10.1093/jhs/hir017

_. 2012, Hindu Theology and Biology: The Bhāgavata Purāna and Contemporary Theory. Oxford: Oxford University Press. http://dx.doi.org/10.1093/acprof:oso/9780 199641543.001 .0001 . 2012a, "The Role of Hindu Theology in the Religion and Science Dialogue." Zygon:
Journal of Religion and Science. Vol. 47, No. 3, pp.624-642, September.

http://dx.doi.org/10.1111/j.1467-

9744.2012.01278.x

- Forthcoming. "Hindu Theology as Churning the Latent." Journal of the American Academy of Religion. http://dx.doi.org/10.1093/jaarel/lfs132

Harrison, Peter, Ronald L. Numbers, and Michael H. Shank. 2011. Wrestling with nature: from omens to science. Chicago: University of Chicago Press.

Hawley, John Stratton, and Vasudha Narayanan. 2006. The life of Hinduism. Berkeley: University of California Press. http://dx.doi.org/10.1525/california/97805 $\underline{20249134.001 .0001}$ 